\title{
The Chinese Advantages Compared with Developed Country in New and Old Energy Converting \& Manufacture Technology
}

Xu Run

Gyeongsang National University, Metallurgical Engineering Department, Gyeongnam, Chinju 52828, Korea

DOI: $10.36348 /$ sjet.2020.v05i11.001

| Received: 16.10 .2020 | Accepted: 03.11.2020 | Published: 06.11.2020

*Corresponding author: Xu Run

Abstract

The new energy is urgent task for us to do. It is not only for contaminated environment but also for resource protection. The basic principle research must be proceeded to keep up with advanced country. Mathematics and applied project will be erected to model all kinds of practice. Auto and robot is two factors to develop manufacture technology. Between them robot is new industrious project for us to erect urgently. The auto is developed through new energy source like electricity and hydrogen etc clean fuel.

Keywords : Chinese Advantages, Developed Country, New and Old Energy Converting, Manufacture Technology, basic principle research.

Copyright (C) 2020 The Author(s): This is an open-access article distributed under the terms of the Creative Commons Attribution 4.0 International License (CC BY-NC 4.0) which permits unrestricted use, distribution, and reproduction in any medium for non-commercial use provided the original author and source are credited.

\section{INTRODUCTION}

The step to a revolution of new energy is now controlled. It is not exploiting resource that remain to us it is a close to environment, such as electricity and clean fuel. They are formed through coal, wind and nuclear which is primary research and modern clean resource. They are not harmful to our bodies and environment [13]. The wind turbine generator is full of sea and mountains because it is no harm generator device. On the contrary it can absorb some energy like typhoon it can protect from rude weather besides it is close to environment. Nuclear power station has a contamination problem when the nuclear leakage happens. How to prevent it from accident is a primary problem. Our strongest project is computer calculation speed to use quantum theory. The speed arrives $110 \mathrm{GHZ}$ per second by D wave mole. It can be used to $5 \mathrm{G}$ with $\mathrm{S}$ mole. Basic research is our strong project because the many quantities graduate students have been formed year by year. In manufacture China has advantage like auto, flighter and robot machine. China has the largest market in the world since its population and development. The cheapest labour is another factor to establish industrious revolution. So the advantage has been wielded to erect new industry. We can attain a high and artificial intelligent new energy revolution. In market the fund and device is used to competitive project to produce high benefit goods. It can arrange fund and labour to fitted position with modelling predict and realize scientific management. So there are still many things for us to do in future. We must catch up with the time demand to benefit mostly. Now in China the own ratio of robot is 48 per thousand. It is $1 / 4$ lower than German and Japan, it is lower than world average of 76 too. We have still many challenges to meet and endeavour every one only.

\section{DISCUSSION}

New energy revolution

Our country although not as good as the United States in terms of population density sparse . Canada but has been far beyond Japan and South Korea. In fact, China has become a semi - developed country in science and technology theory and practice. In particular, the great theoretical achievements, the reason is that low - and middle-income countries often in the theoretical attainments deep. China has broken through the boundaries of key areas of theoretical robotics and is poised to become a powerhouse in the field of theoretical robotics in the future, according to a paper in The Chinese Journal of Mechanical Engineering. In practice, China's scientific inquiry also plays a decisive role, which is the result of the improvement of economic level. China's GDP has entered the threshold of ten thousand dollars, marking a step forward to the middle and upper class countries. This was followed by the development of science and technology and the improvement of the quality of life, such as the improvement of the quantity and quality of papers and the popularization of automobiles. The emergence of 
Xu Run; Saudi J Eng Technol, Nov, 2020; 5(11): 410-412

new energy vehicles will drive the transformation of a whole industrial chain and the conversion of old and new driving forces. The old and new conversion of kinetic energy is a new industry , constantly emerging of new forms and new patterns. Its essence is to use the energy of resources and improve the environment. Because the gasoline-based industry will become a revolution fueled by electricity and hydrogen, the manufacturing of new energy vehicles will fundamentally change the industrial structure and industrial chain. It will promote a new layout of industry and a marked improvement in the quality of people's lives. Low-carbon life will soon realize, electricity, low noise and low pollution of hydrogen will completely change the human rely on the history of the oil and water resources widely wind and solar energy become the main source of human energy. Oil will become a thing of the past and new energy will play its role more and more. For example, wind turbines and tidal generators, which convert wind and huge ocean tides into energy, play an increasingly important role for the benefit of mankind. It is becoming more and more important to reduce the exploitation of resources and protect the ecological environment for future generations. Scientific and technological innovation has become the main theme, driving the conversion of old and new driving forces, vigorously advocating the manufacture and utilization of new-energy vehicles, and promoting the transformation of industrial chain. Usher in the future new environment, comfortable and convenient life, in order to favor offspring. Stop drilling for oil and switch to natural gas, develop hydrogen batteries, save resources and reduce emissions. Scientific and technological innovation needs to do a good job in the development and utilization of hydrogen fuel, water as the main new energy in the future. From cars to the storage of electricity, the use of abundant water will solve mankind's future energy problems. Scientific research and technological innovation need to focus on hydrogen fuel and the development of preparation is a top priority. Since hydrogen fuel and its preparation eventually form water to protect the environment, it is a dual-benefit material that is beneficial to both resources and the environment. Therefore, scientific research and innovation are urgently needed to make due contributions to the future of mankind. China's 2019 GDP (gross domestic product), 100 trillion (100 trillions) $\$ \$ 14$ trillions (then change rate).

\section{Basic science research}

Controlling population growth, improving national quality and enhancing scientific and technological level are the keys to ensure China's transition to an advanced country in the world. The problems to be solved in the next 30 years cannot wait from now. On the whole, China's educational level has been greatly improved. The average annual share of college students has increased from 600,000 in 1990 to 3 million now, which has increased by nearly five times in 30 years. The number of master students has increased from 100,000 in 1994 to 500,000 now, which has increased by five times in the same period. The number of postgraduate applicants reached 2.38 million in $2018,370,000$ more than in 2017.From this data we can see that Our country is getting closer and closer to the advanced countries. But there is still a lack of quality, practice is not enough, theory is more than practice. Catching up with Japan and the United States requires more efforts in practicality and depth, because China is in the world's advanced position in basic theory, because it can be used in a moderate amount without equipment, and has reached the world's advanced level in terms of number of people. But in practice, due to economic reasons, creativity is not monotonous and there are many repetitions, which hinders China from becoming the world's advanced in high-tech. They are divided basic and applied science including mathematics and computer, controlling etc. The foundation should be invested to these fields to anticipate better effect. To choose person with ability to complete all kinds of fields for the advanced application like aeronautic \& space science etc. As for biology \&chemistry new person is chosen to proceed $\mathrm{R} \& \mathrm{D}$ (research and development) for new medicine etc in institute and corporation. As known in America this direct is emphasized and paid attention to in many institutes. According to the statistic the chinese oversea students attain 380 thousand in America and 9 thousand in the other countries in recent respectively. This is a cherished human resource for us to use in future.

\section{MANUFACTURE TECHNOLOGY}

In the moderate dynamic equilibrium state can improve the life of the vehicle and so on. It's a graph of the relationship between quantity and cost. They are dynamic rather than static. Increase the cost when the quantity is high and not when it is low or increase the cost slightly. This is dynamic equilibrium. Large dynamics have no controllability and are not used for cost analysis. It is the proper balance that is controllable, that is the purpose of our study.

If the automotive acceleration into the primary position then the design needs to put the engine load power. If stability is taken as the first line, the bottom bridge spring should be redesigned and adjusted to the car weight. Improve wheelbase, wheelbase and interior if space and comfort are a priority.

1. The appointment of engineers enables the implementation of the creation of enterprise products. To grasp the primary purpose can achieve the purpose of product function update, launch new products to meet the needs of consumers at the main level of social sales. Reduce time to produce new products and increase design cycle time. At some point in the first design the second design began to roll out. The third and fourth styles are also released timely to maintain the continuity of product design. 
2. Make articles on the main performance aspects, follow up the aspects that can be improved, and make articles. This can improve performance, stand out from the crowd, increase sales.Other aspects need to reduce the design time, so as to do well in the primary aspect, the secondary to speed up the adoption, to ensure that the primary purpose smoothly.Focus on personality to improve the main functionality of the product.

\section{CONCLUSIONS}

New energy includes wind generator, nuclear generator,computer science and electric auto. Hybrid auto is applied to citizen live with large quantity so it is the most important project. Basic principle is necessary for our graduate students even overseas to do. Mathematics and applied field is two main tasks. In manufacture the Chinese auto is the biggest market in the world so we must erect artificial intelligent auto equipment for increasing sale quantity and low cost with clean fuel like electricity and hydrogen fuel. Robot is a new industry in the world. It can complete difficult tasks for human so we must erect this industry urgently.

\section{REFERENCES}

1. Yang, R. (2017). Cost management [M]. East China normal university press, 47

2. Compilation group of economics textbook series. (2013). Microeconomics [M], economic science press, 106

3. Jing, F.Z.F. (2016). Marketing research [M]. Higher education press, 105

\section{Brief Biography}

XU Run is a PHD completion student in school of Material Engineering Department in Geongsang National University. His research direction is material of metal cutting. Xurun1206@163.com 